Boletín de la Sociedad Geológica Mexicana

VOLUMEN 61, NÚM. 3, 2009, P. 367-374

\title{
Late Triassic and Early Cretaceous sedimentary sequences of the northern Isfahan Province (Central Iran): stratigraphy and paleoenvironments
}

\author{
Maryam Mannani ${ }^{1, *}$, Mehdi Yazdi ${ }^{1}$ \\ ${ }^{1}$ Department of Geology, University of Isfahan, Isfahan, Iran. \\ *mannani_m@yahoo.com
}

\begin{abstract}
This research gives a general outline of the Upper Triassic and Lower Cretaceous sequences cropping out north of Isfahan, Central Iran. Upper Triassic Nayband Formation subdivided into the Gelkan, Bidestan, Howz-e-Sheikh, Howz-e Khan and Qadir members. Two biostromal levels are documented in the Bidestan and Howz-e-Khan members. Due to a suitable condition in Late Triassic time including light, oxygen and nutrient, fauna such as: corals, sponges, hydrozoas, bivalves, gastropods, brachiopods, echinoderms and Dicroidium were flourished in water and flora on land. The first appearance of Heterastridium spp. in level of the Bidestan Member is apparently the first occurrence of this taxon in Central Iran. Qadir Member has several key beds, one key bed with land flora Clathropteris spp., and three key beds with bivalve Indopecten glabra, dating as Rhaetian Stage. An angular unconformity can be traced between Rhaetian sediments and red conglomerates and sandstones of Lower Cretaceous Sequences in Isfahan area which encompasses all Jurassic rocks. This gap can be related to Cimmerian tectonic phase.
\end{abstract}

Keywords: Upper Triassic, Lower Cretaceous, Nayband Formation, Isfahan Province, Cimmerian.

\section{Resumen}

Este estudio provee de un esquema general de las secuencias del Triásico Superior y Cretáceo Inferior localizadas al norte de Isfahan, en el Centro de Irán. La formación Nayband del Triásico Superior está subdividida en los miembros Gelkan, Bidestan, Howze-Sheikh, Howz-e-Khan y Qadir. Dos niveles de biostroma están documentados en los miembros Bidestan y Howz-e-Khan. Debido a las condiciones favorables en el Triásico tardio que incluyeron luz, oxígeno y nutrientes, fauna como: corales, esponjas, hidrozoarios, bivalvos, gasterópodos, braquiópodos, equinodermos y Dicroidium prosperaron en el agua y la flora en tierra. La presencia de Heterastridium spp. en el nivel del Miembro Bidestan es aparentemente el primer registro de este taxón el Centro de Irán. El miembro Qadir tiene varios estratos índice, uno de ellos con flora terrestre Clathropteris spp., y tres estratos indice con el bivalvo Indopecten glabra, fechados como etapa Rhaetian. Una disconformidad angular se puede trazar entre los sedimentos Rhaetian, conglomerados rojos, y areniscas provenientes de Secuencias del Cretáceo inferior en el área de Isfahan que incluye a todas las rocas del Jurásico. Esta discontinuidad puede estar relacionada con la fase tectónica Cimmeriana.

Palabras clave: Triásico Superior, Cretáceo Inferior, Formación Nayband, Provincia de Isfahan, Cimmeriana. 


\section{Introduction}

Upper Triassic and Lower Cretaceous rocks are spread widely in central and northern Iran. The major objective of the present study is the Upper Triassic (Norian to Rhaetian) sediments of the Nayband Formation exposed in three sections located in Dombi and Bagher Abad, north of Isfahan Province. In these localities, the Triassic deposits are overlain with a distinct angular unconformity by the Lower Cretaceous deposits, whereas Jurassic sediments are missing almost completely. The unit of conglomerate at the base of the Lower Cretaceous contains pebbles of carbonate and siliciclastic rocks without any sign of the Jurassic fossils.

The Nayband Formation contains abundant and taxonomically diverse marine invertebrate fauna. Since pioneering studies by Douglas (1929) who introduced the Nayband Formation and subdivided it into three members, sedimentology, biostratigraphy and palaeontology of this lithostratigraphical unit was outlined in numerous publications including Brönnimann et al. (1971), Kluyver et al. (1983), Fürsich et al. (2005), Seyed-Emami (1971, 2003), Zahedi (1976) and Hautmann (2001). Extensive studies on bivalve and gastropod molluscs from the Nayband Formation were published by Douglas 1929, Fallahi et al. (1983), Nützel and Senowbari-Daryan (1999), and Nützel et al. (2003). Valuable data on the Late Triassic paleoenvironment based on palaeoecological studies of bivalves were published by Repine (1996). Further data on the Triassic and Lower Cretaceous stratigraphy of Iran can be found in publications by Aghanabati (1998, 2006). Davoudzadeh and Schmid (1981) reported effects of the mid to late Cimmerian orogenic phase in Iran. Berberian and King (1981) studied on evolution of paleogeography in Iran. Golonka $(2004,2007)$ studied on evolution of plate tectonic of Eurasia margins and world in Mesozoic. Ghasemi and Talbot (2005) work on tectonic of Sannandaj- Sirjan Zone. (Fig. 1) shows Map of Geological Zones of Iran (knol. Google. Com).

\section{Geological setting}

Two studied sections ( $\mathrm{B}$ and $\mathrm{C}$ ) are situated about $35 \mathrm{~km}$ north-east of Isfahan, in the area located $10 \mathrm{~km}$ east of the Dizlu village, and $15 \mathrm{~km}$ north-east of Bagher Abad village $\left(33^{\circ} 4^{\prime} \mathrm{N}, 52^{\circ} 2^{\prime} \mathrm{E}\right)$. The third section (A) is situated about $30 \mathrm{~km}$ west of Dizlu section, in the outskirts of the Dombi village $\left(33^{\circ} 3\right.$ ' 3' N, 51 ${ }^{\circ} 52^{\prime}$ '20' E) (Fig. 2).

The Upper Triassic Nayband Formation in these sections can be subdivided into:

(1) the Gelkan Member of shales and sandstones; (2) the Bidestan Member of oolithic limestones, sandstones and reefal limestones with numerous algae, calcareous sponges and corals; (3) the Howz-e-Sheikh Member of shales and sandstones; (4) the Howz-e-Khan Member of reefal limestones with algae, calcareous sponges and corals.
The overlying sediments are referred informally to the Qadir Member (Fig. 3).

The Triassic lithostratigraphy applied to the studied sections was established by Brönnimann et al. (1971); Kluyver et al. (1983) and Fürsich et al. (2005), who gave a comprehensive outline of geology and facies of the Nayband Formation.

In the studied area, the Nayband Formation rests conformably on the Middle Triassic Shotori Dolomite. The Gelkan Member, up to $400 \mathrm{~m}$ thick, which is the lowermost lithostratigraphic unit within the Upper Triassic sequence, comprises intercalating shale and dark green sandstone beds with cross bedding and ripple marks. The succeeding Bidestan Member is about $11 \mathrm{~m}$ thick and it starts with oolitic limestones containing abundant spherical hydrozoan Heterastridium spp. indicating the Norian age. Biostromal bioconstructions are also present. Sponges and corals are the main reef building organisms in the biostromes. Heterastridium spp. and bivalves are also relatively abundant. Corals such as: Distichophyllia cf. Norica, Retiophyllia clathrata, Astraeomorpha crassisepta, Crassistella juvavica. The Howz-e-Sheikh Member, up to $44 \mathrm{~m}$ thick consists mainly of light brown, barren, bedded sandstone. The overlying Howz-e-Khan Member, up to $15 \mathrm{~m}$ thick, starts with a thick limestone bed. It contains abundant reef building organisms, including: Sponges, Corals (Distichophyllia cf. Norica, Oedalmia norica, Retiophyllia norica, Cuifia columnaris, Cuifia gigantella, Distichomeandra austriaca, Astraeomorp confusa, Crassistella juvavica) as well as reef dwellers represented by echinoderms, bivalves, brachiopods and gastropods (Protorcula sp., Anulifera binodosa, Anulifera variabilis, Cryptaulax inaequelineata, Purpuroidea dilophosignata). The uppermost Qadir Member comprises intercalating sandstones and marls total up to $200 \mathrm{~m}$ think. It contains bivalve mollusc (Indopecten glabra) and flora (Clathropteris sp.) indicative of the Rhaetian Stage, which occurs up to the top of the unit. The Triassic sequence is overlain unconformably by the Lower Cretaceous of conglomerates and sandstones with some thin beds of coal (Fig. 4, c, d, f). Two horizons of terrestrial deposits can be recognized in the Lower Cretaceous in the north of Isfahan. They contain basal beds of conglomerate, but there is no evidence of sedimentation though the Jurassic in the area both in situ and from sedimentary clasts suggesting that regime of terrestrial exposition and erosion prevailed until beginning of the Cretaceous.

\section{Discussion}

The siliciclastic sedimentation prevailed during deposition of the Gelkan Member, which constitutes the basal unit of the Nayband Formation. Occurrence of wave ripple marks and bidirectional cross bedding in the sandstones suggest very shallow, peritidal to upper subtidal 


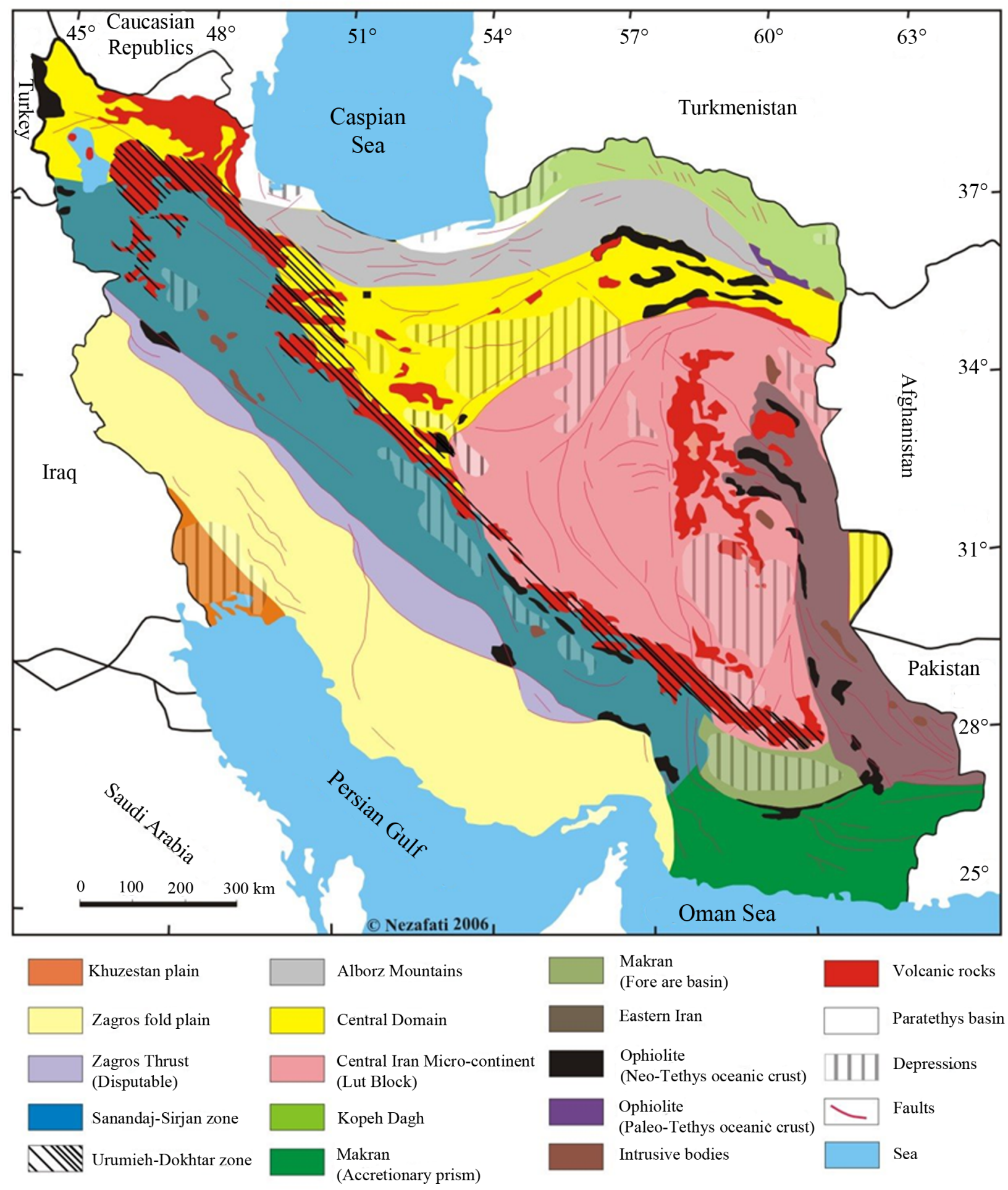

Figure 1. Map of Geological Zones of Iran (knol. Google. Com).

depositional environment. Carbonate sedimentation in the area started with deposition of oolitic limestone bed, which is the lowermost unit within the overlying Bidestan Member. Abundance of algae, corals and calcareous sponges, and a presence of the biostrom horizon suggest that the Bidestan
Member was formed in well oxygenized, shallow marine environment within euphotic zone rich in nutrients and periodically affected by seasonal storms. The taxonomic composition of the fauna and occurrence of Heterastridium spp. are characteristic of the Norian Stage. Siliciclastic 

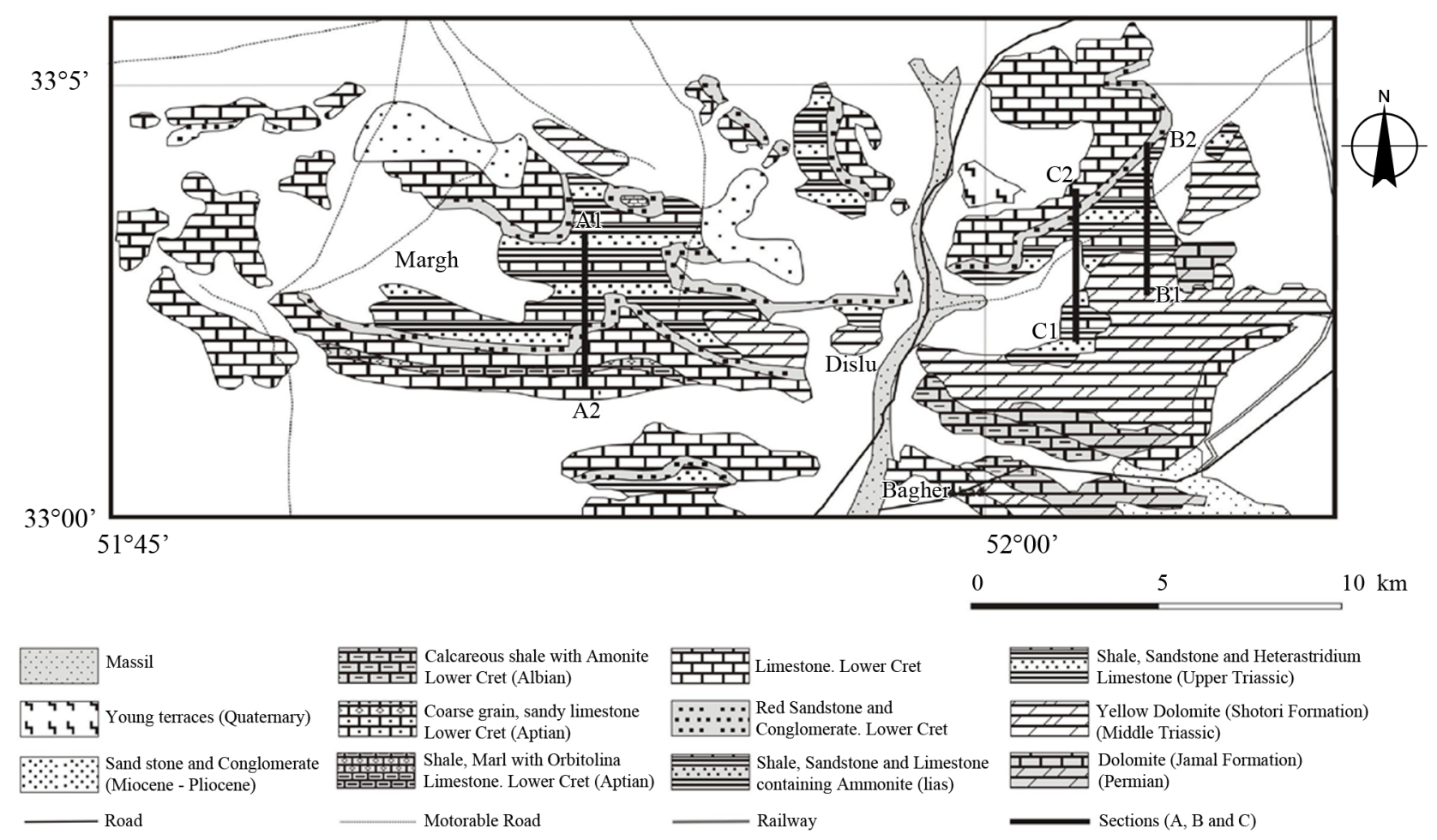

Figure 2. Studied area in North of Isfahan, Bagher Abad area (B1- B2 and C1- C2); Dombi area (A1- A2).

sedimentation was restored during formation of the succeeding Howz-e-Sheikh Member, however conditions favorable reef builders restored during formation of the Howz-e-Khan Member, which contains a second biostrom horizon up to $15 \mathrm{~m}$ thick in the lower part. Diversity of the faunal assemblage associated with these organic build-ups, including various sponges, corals, bivalves, gastropods, brachiopods and echinoderms, exceeds significantly faunal diversity recorded for the Bidestan Member. The hydrozoan Heterastridium conglobatum proliferates in this environment and it was grown up to $20 \mathrm{~cm}$ in diameter (Fig 5a-e), which is significantly larger than the specimens derived from the Bidestan Member where they do not exceed $4 \mathrm{~cm}$ in diameter. It is likely that Heterastridium from the Bidestan Member represent a different species.

The upper part of the Qadir Member comprises intercalating sandstones and argillaceous limestones with a distinct fossiliferous horizon containing flora remains assigned to the Clathropteris sp. (Fig. 4a) and three shell beds formed by the bivalve Indopecten glabra (Fig. 5f). These beds are confined to the Rhaetian Stage.

During the Early Cretaceous, terrestrial conditions prevailed in the studied area. Conglomerate and sandstone beds contain scattered broken pieces of wood suggesting the Neocomian (Barremian).

\subsection{Cimmerian tectonic phase}

The Jurassic period was the important time in the geological history of Central Iran, because it coincides with the accretion of several Iranian terrenes to the southern margin of Euroasia. According to the recent plate tectonic reconstructions (Golonka, 2000, 2002; Golonka and Ford, 2000) Central Iran was within the system of the Cimmerian plates which rifted from the Gondwanan margin sometime in the Late Carboniferous-Permian time drifted northward, towards Euroasia during the Triassic. This collision resulted in a closure of the Palaeotethys Ocean and series of events related to the tectonic uplift, magmatism and metamorphism traditionally characterized in the Iranian geological literature as the Early Cimmerian orogeny (Aghanabati, 1998).

It is probable that the stratigraphic gap between Late Triassic to Early Cretaceous reflects a compressional regime and an uplift which coincides with the closure of the Palaeotethys Ocean. Mid Cimmerian orogeny in Central Iran was started in the Bathonian (Aghanabati, 1998). There is a big gap between Late Triassic and Lower Jurassic to Early Barremian documented in Central Iran. Wide spread unconformity at this level is reported from Qazvin and Taleghan (Annelles, 1975), as well as in northern Kerman Province and in Djam-e-Semnan Province (Central Iran). In Kopet-Dagh region is an angular unconformity between Kashafrud Formation and Late Triassic sediments (Aghanabati, 1998).

The base of the Early Cretaceous in Central Iran is defined by the characteristic unit of red conglomerate, which contains scattered fossil wood fragments and thin coal beds. Then deposition of the marine sediments commenced. The 

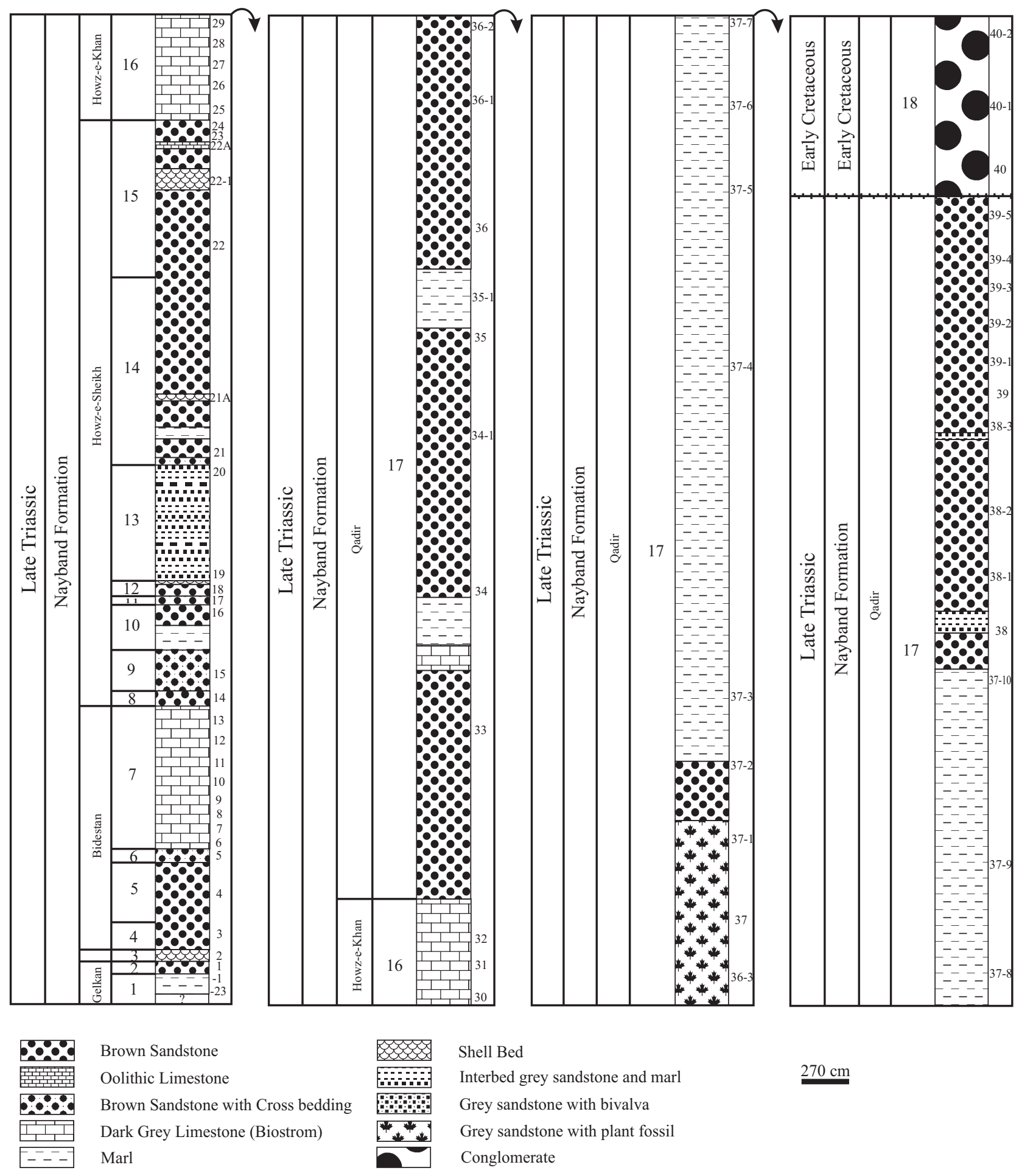

Shell Bed

Interbed grey sandstone and marl

$270 \mathrm{~cm}$

Grey sandstone with bivalva

Grey sandstone with plant fossil

Conglomerate

Figure 3. Stratigraphical column of Nayband Formation in Bagher Abad area, North of Isfahan.

conglomerate unit contains pebbles mostly of siliciclastic rocks (up to $80 \%$ ), but also dolomites derived from the Shotori Formation (Fig. 4b). In the Soh area, $140 \mathrm{~km}$ north of Isfahan, basal Cretaceous conglomerates contain clasts derived from the Upper Triassic biostrom build-ups
(Kimiagari, 1995). Kolah Ghazi Granitoeed located in 50 $\mathrm{km}$ South- East South of Isfahan. This igneous component is belonging to Sanandaj-Sirjan Zone. Granitoide created contact metamorphic in the shale and sandstone normally in the age of Rhaetian to Early Cretaceous time interval 


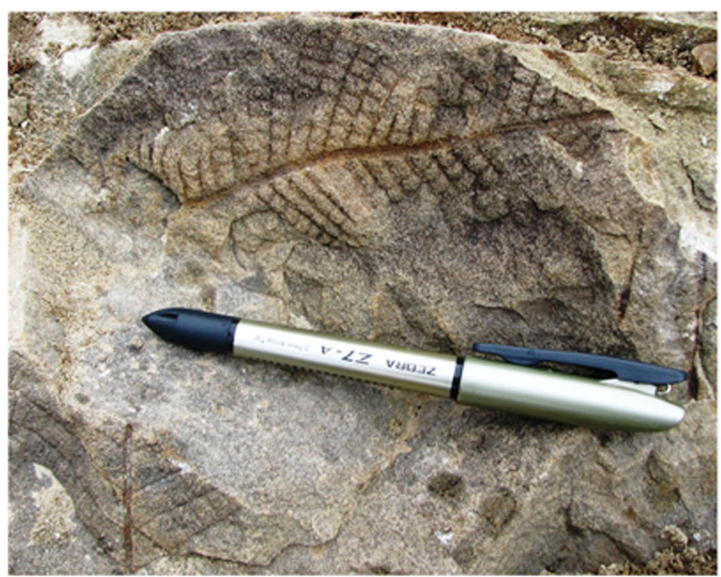

a

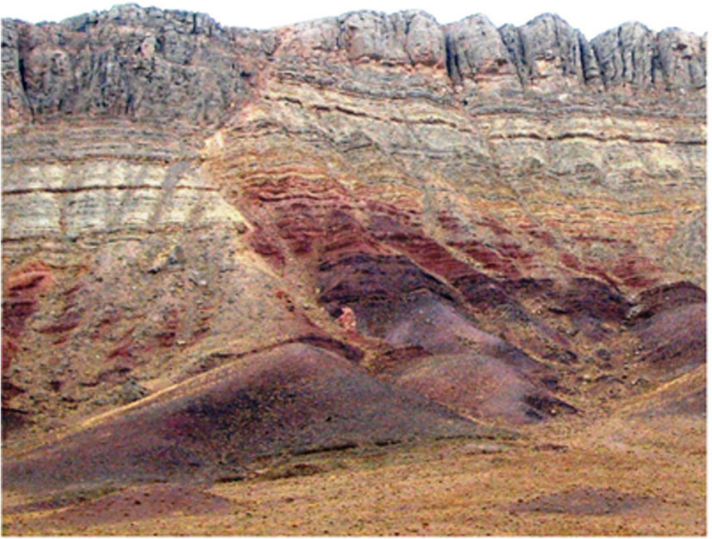

c

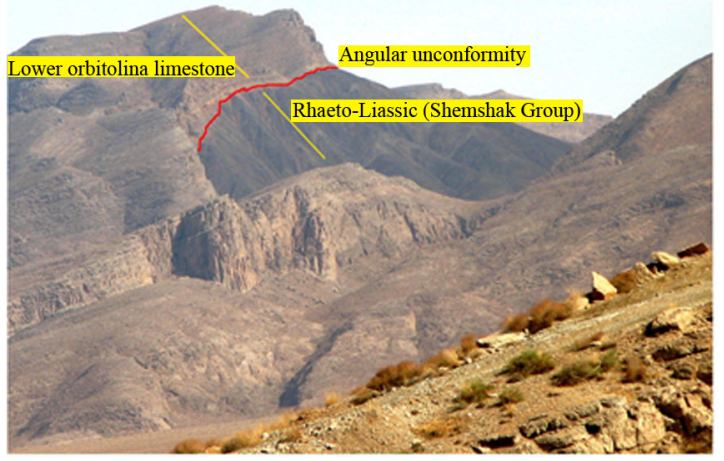

e

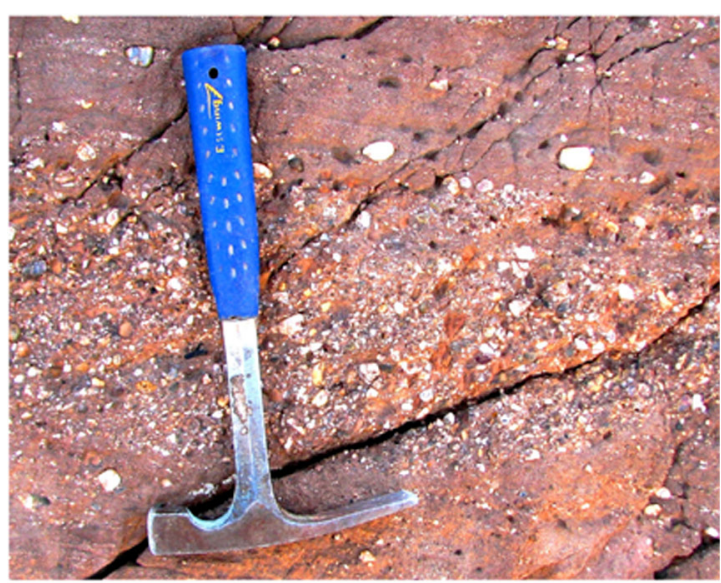

b

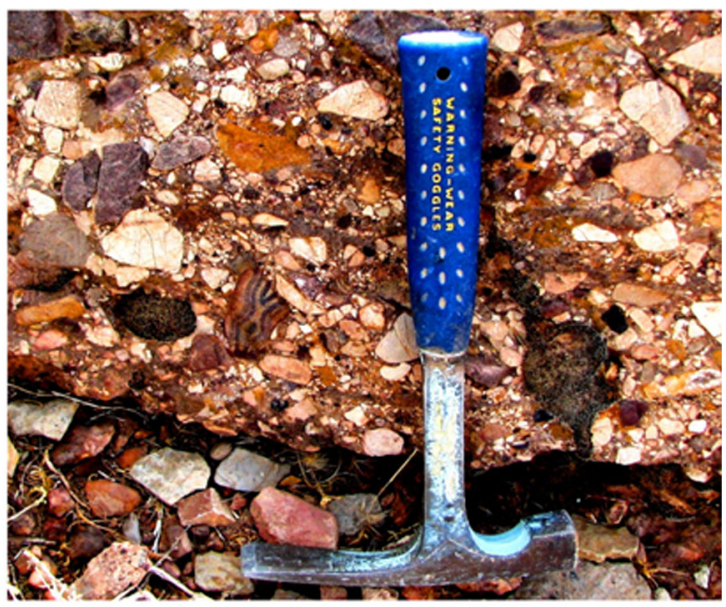

d

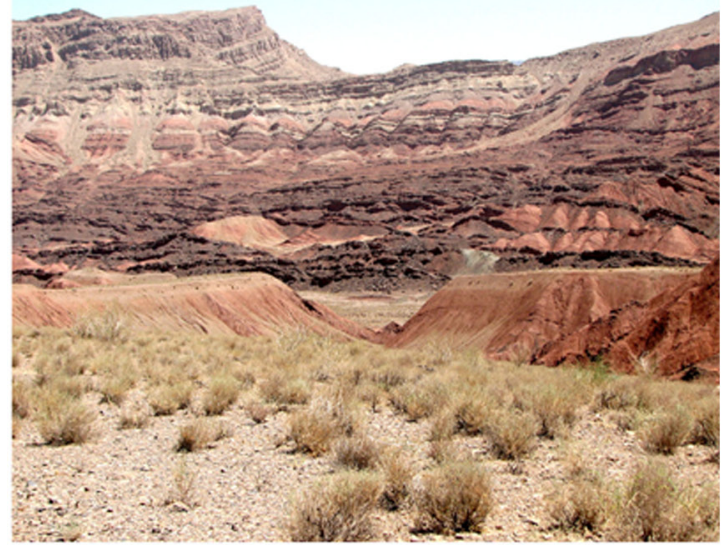

f

Figure 4. a) Plant key bed in Qadir Member, Nayband Formation in Bagher Abad area, North of Isfahan, b) Early Cretaceous conglomerate in Izadkhast area, south of Isfahan, c) Angular unconformity between Early Cretaceous and Rhaeto- Liassic sequences in Bagher Abad area, North of Isfahan, d) Pebbles of Early Cretaceous conglomerate in Dombi area, North of Isfahan, e) Angular unconformity between Early Cretaceous and Rhaeto-Liassic sequences in Kolah Ghazi, South-East South of Isfahan (after Yazdi et al., 2009), f) Bidou Formation, North of Kerman. 


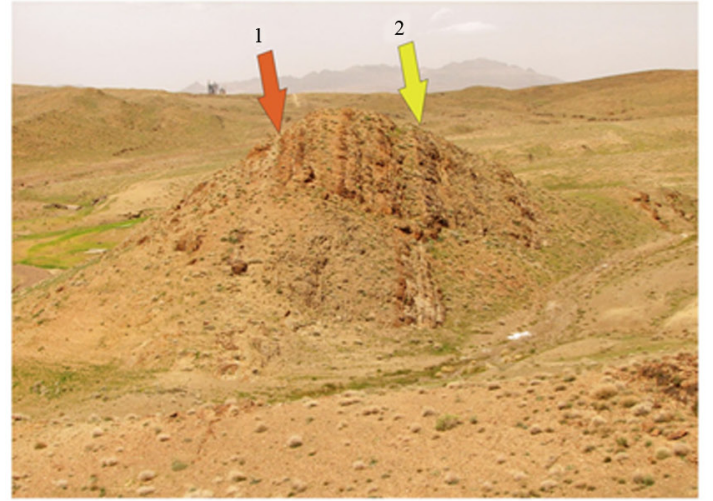

a

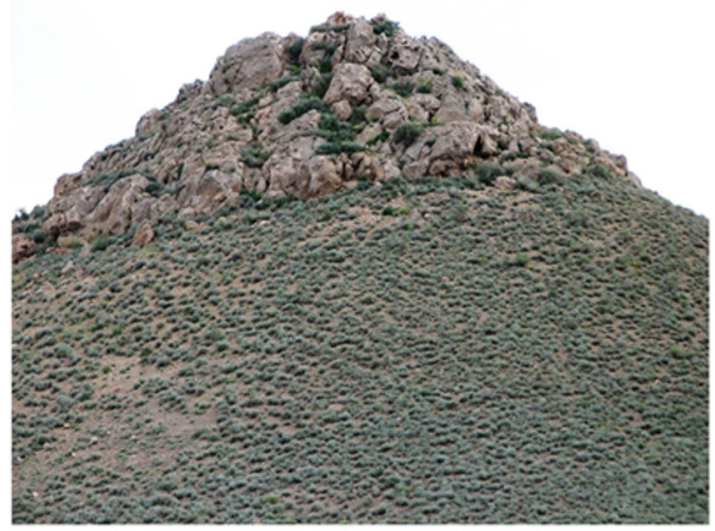

c

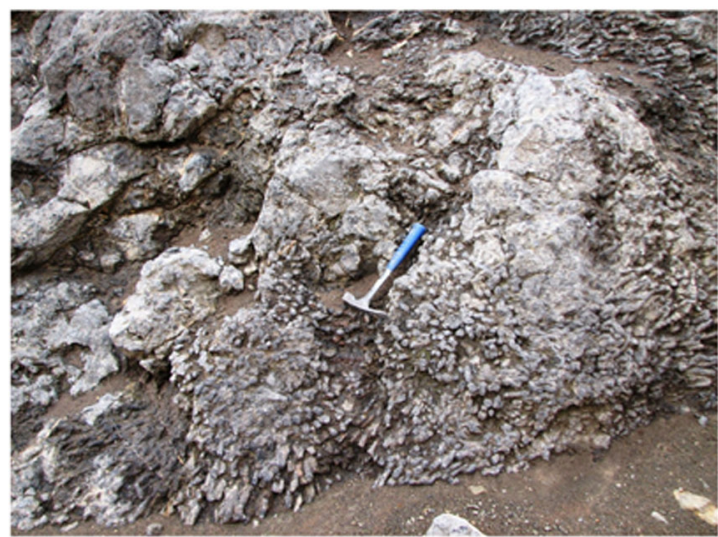

e

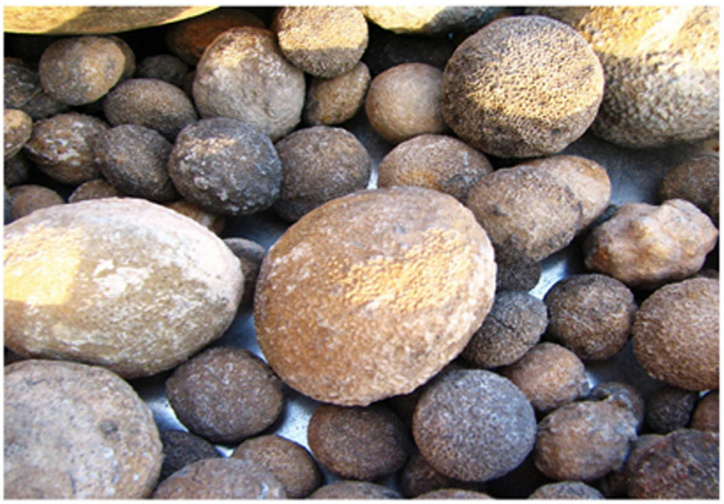

b

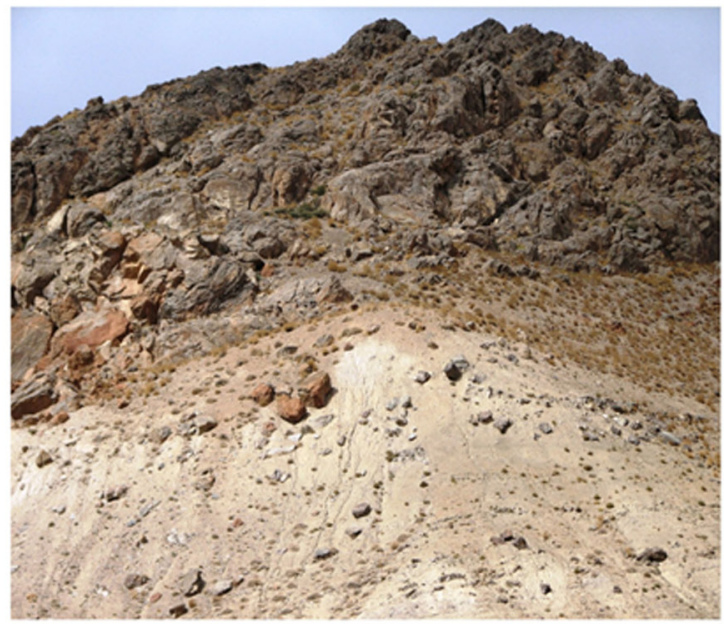

d

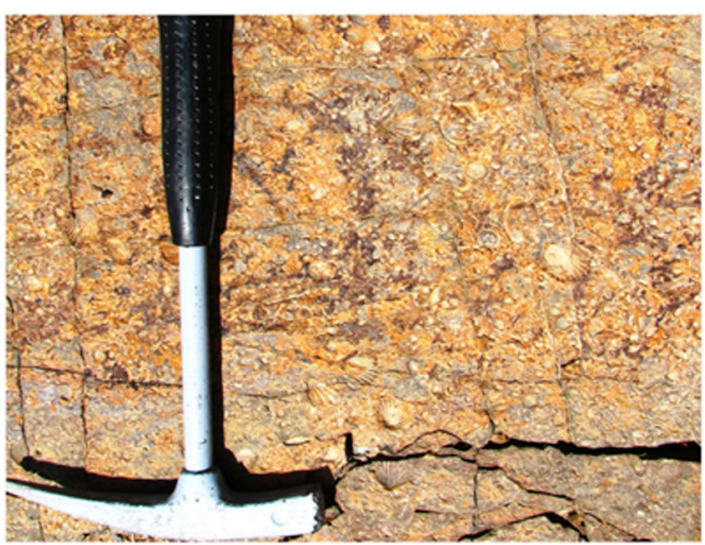

f

Figure 5. a) Biostrom 1, 2, Nayband Formation, Bagher Abad area, North of Isfahan, b) Heterastridium spp. in Howz-e-Khan Member, Nayband Formation, c) Grey reefal limestone in, Nayband Formation Delijan area, North of Isfahan, d) Grey reefal limestone in, Nayband Formation, Soh area, North of Isfahan, e) Colony of Corals in Howz-e-Khan Member, Nayband Formation, Bagher Abad area, North of Isfahan, f) Bivalve key bed in Qadir Member, Nayband Formation, Bagher Abad area, North of Isfahan. 
(Tabatabaee, 1995) (Fig. 4e).

Unlike Central Iran and parts of the Alborz region, continuous marine sedimentation across the Jurassic Cretaceous boundary is characteristic for the Zagros and Kopet Dagh regions (Jamadi, 1998).

\section{Conclusion}

Faunal association of Bidestan and Howz-e-Khan Members characterized Norian- Rhaetian stages. Qadir Member contains Clathropteris sp. and Indopecten glabra. They indicated Rhaetian stage. Nayband formation is overlain unconformably by the Lower Cretaceous of conglomerates and sandstones. One big gap can be recognized in Jurassic time in Central Iran. Red conglomerate show transgression phenomena at the time of Early Cretaceous in Central Iran. Pebbles of conglomerate have several sources. There is no evidence of Jurassic fossils like Ammonite or microfossil in Early Cretaceous conglomerate. The lack of a part of Liassic, Dogger and Malm and Neocomian sediments related to Cimmerian phase.

\section{Acknowledgments}

We thank the office of Graduate studies of the University of Isfahan for its support. We thank sincerely Professor F. Vega who helped us with his guidance. We thank Dr A. Bahrami most sincerely for his assistance during the preparation of this paper. We should like to thank Miss M. Bostankar and Mr. R. Nejat most kindly for their cooperation to prepare this article.

\section{References}

Aghanabati, S.A., 1998, Jurassic Stratigraphy of Iran: Geological Survey of Iran, 746 p, (in Persian).

Aghanabati, S.A., 2006, Geology of Iran: Geological Survey of Iran, 586p, (in Persian).

Annelles, R.N., 1975, Explanatory text of Qazvin and Rasht Quadrangle Map, 1:250,000: Geological Survey of Iran, Quadrangles E3, E4: $1-94$.

Berberian, M., King, G.C., 1981, Towards a paleogeography and tectonic evaluation of Iran: Canadian Journal of Earth Science, 18 (2), 210-265.

Brönnimann, P., Zaninetti, L., Bozorghnia, F., Dashti, G.R., Moshthaghian, A., 1971, Lithostratigraphy and foraminifera of the Upper Triassic Nayband Formation Iran: Revue de Micropaléontologie, 14, 7-16.

Davoudzadeh, M., Schmid, K., 1981, Contribution to the paleogeography and stratigraphy of the Upper Triassic to Middle Jurassic of Iran. Neues Jahrbuch für Geologie und Paläontologie - Abhandlungen, $162,137-162$

Douglas, J.A., 1929, A marine Triassic fauna from eastern Persia: Quarterly Journal of the Geological Society of London, 85(340), 625- 650.
Fallahi, M., Gruber, B., Tichy, G., 1983, Gastropoden und Bivalven aus dem oberen Teil der Nayband-Formation (Obertrias) von Baqirabad (Isfahan, Iran): Schriftenreihe der Erdwissenschaftlichen Kommissionen, 5, 57-82.

Fürsich, F.T., Hautmann, M., Senowbari-Darian, B., Seyed-Emami, K., 2005, The Upper Triassic Nayband and Darkuh formations of eastcentral Iran, Stratigraphy, facies patterns and biota of extensional basins on an accreted terrane: Beringeria, 35, 53-133.

Ghasemi, A., Talbot, C.J., 2006, A new tectonic scenario for the SanandajSirjan Zone (Iran): Journal of Asian Earth Sciences, 26, 683-693.

Golonka, J., 2000, Cambrian-Neogene Plate Tectonic Maps: Wydawnictwa Uniwersytetu Jagiellońskiego, Kraków.

Golonka, J., 2002, Plate-tectonic Maps of the Phanerozoic, in Kiessling, W., Flügel, E., Golonka, J. (Eds.), Phanerozoic Reef Patterns: SEPM (Society for Sedimentary Geology), Special Publication, 72, 21-75.

Golonka, J., 2004, Plate tectonic evolution of the southern margin of Eurasia in the Mesozoic and Cenozoic: Tectonophysics, 381, $235-273$.

Golonka J., 2007, Late Triassic and Early Jurassic paleogeography of the world: Palaeogeography, Palaeoclimatology, Palaeoecology, 244, 297-307.

Golonka, J., Ford, D.W., 2000, Pangean (late Carboniferous - Middle Jurassic) paleoenvironment and lithofacies: Palaeogeography, Palaeoclimatology, Palaeoecology, 161, 1-34.

Hautmann, M., 2001, Die Muschelfauna der Nayband - formation (obertrias, Nor-Rhät) des östlichen Zentraliran: Beringeria, 29, $1-181$.

Jamadi, L., 1998, Biostratigraphy and Stratigraphy of Early Cretaceous Sediments in East of Isfahan: Iran, University of Isfahan, MS thesis, (in Persian).

Kimiagary, M., 1995, Geological study and Stratigraphy Early Cretaceous Sediments in Soh area (South of Kashan): Iran, University of Isfahan, MS thesis, (in Persian).

Kluyver, H.M., Griffis, R.J., Tirrul, R., Chance, P. N., Meixner, H. M., 1983, Explanatory text of the Lakar Kuh Quadrangle Map 1: 250,000: Geological Survey of Iran, J9: 1- 175.

Nützel, A., Senowbari-Darian, B., 1999, Gastropods from the Upper Triassic (Norian-Rhaetian) Nayband Formation of central Iran: Beringeria, 23, 93-132.

Nützel, A., Hamedani, A., Senowbari-Darian, B., 2003, Some Late Triassic Gastropods from the Nayband Formation in Central Iran: Facies, $48,127-134$

Repine, U., 1996, New Late Triassic Bivalves from Iran and a taxonomy of the superfamily Spondylacea: Paleontological Journal, 30 (4), 363-369.

Seyed-Emami, K., 1971, A summary of the Triassic in Iran: Geological Survey of Iran, Report, 20, 41-53.

Seyed-Emami, K., 2003, Triassic in Iran: Facies, 48, 91-106.

Tabatabaee, M., 1995, Petrology of intrusive body in Kolah ghazi area (South- East South of Isfahan): Iran, University of Isfahan, MS thesis, (in Persian).

Yazdi, M., Bahrami, A., Vega, F., 2009, Albian decapod Crustacea from Southeast Isfahan, Central Iran-Kolah-Qazi area: Bulletin of the Mizunami Fossil Museum, 35, 71-77.

Zahedi, M., 1976, Explanatory text of the Isfahan Quadrangle 1:250,000. Geological Survey of Iran, F8, 49.

Manuscript received: August 26, 2009.

Corrected manuscript received: October 5, 2009.

Manuscript accepted: October 18, 2009. 